\title{
Medication-related visits in a pediatric emergency department: an 8-years retrospective analysis
}

Cristiano Rosafio ${ }^{1 *}$, Serena Paioli ${ }^{2}$, Cinzia Del Giovane ${ }^{3}$, Valentina Cenciarelli ${ }^{1}$, Nilla Viani ${ }^{4}$, Paolo Bertolani ${ }^{5}$ and Lorenzo lughetti ${ }^{1,2,3,4,5}$

\begin{abstract}
Background: There are limited data on the characterization of medication-related visits (MRVs) to the emergency department (ED) in pediatric patients in Italy. We have estimated the frequency, severity, and classification of MRVs to the ED in pediatric patients.

Methods: We retrospectively analyzed data for children seeking medical evaluation for a MRV over an 8 years period. A medication-related ED visit was identified by using a random pharmacist assessment, emergency physician assessment, and in case of conflicting events, by a third investigators random assessment.

Results: In this study, regarding a single tertiary center in Italy, on a total of 147,643 patients from 0 to 14 years old, 497 medication-related visits were found, 54\% of which occurred in children from 0 to 2 years of age. Severity was classified as mild in $21.6 \%$ of cases, moderate in $67.2 \%$ of cases, and severe in $11.2 \%$ of cases. The most common events were related to drug use without indication (51\%), adverse drug reactions (30.3\%), supratherapeutic dosage (13.2\%) and improper drug selection (4.5\%).

The medication classes most frequently implicated in an ADE were anti-infective drugs for systemic use (28. $9 \%)$, central nervous system agents (22.3\%) and respiratory system drugs (10.8\%).

The most common symptom manifestations were dermatologic conditions (46.1\%), general disorder and administration site conditions (29.7\%) and gastrointestinal symptoms (16.0\%).

Conclusions: To our knowledge, this is the first study in Italy evaluating the epidemiologic characteristics of MRVs confirming a significant cause of healthcare contact resulting in ED visits and hospital admissions with associated resource utilization. Our results suggests further future prospective, large-sample sized, and multicenter research is necessary to better understand the impact of MRVs and to develop strategies to provide care plans and monitor patients to prevent medication-related visits.
\end{abstract}

Trial registration: Not applicable.

Keywords: Medication related events, Medication-related event visits, Medication-related visit, Adverse drug events, Adverse drug reactions, Medication error, Emergency department

\footnotetext{
* Correspondence: cristiano.rosafio@gmail.com

${ }^{1}$ Pediatric Unit, Post Graduate School of Pediatrics, University of Modena and

Reggio Emilia, Viale del Pozzo, 71, 41124 Modena, Italy

Full list of author information is available at the end of the article
} 


\section{Background}

Medication related events (MREs) are disadvantageous occurences, mostly preventable, related to use of a drug $[1,2]$.

It has been estimated that MREs are a significant problem in term of impact of consultations in Emergency Department (ED) and hospital admission in pediatric patients, contributing to overall pressures on health care system [3-5]. Previous studies focused on adverse drug events (ADEs) involved different methodologies and a spectrum of different inclusion criteria, ranged from studies of narrowly defined adverse drug reactions (ADRs) to more broadly defined medicationrelated events" [4, 6-44].

The Italian active pharmacovigilance project 'Monitoring of the adverse effects in pediatric population' (MEAP), aimed to assess pediatric ADRs, provided a valid strategy to identify previously unknown ADRs, reduce underreporting and increase awareness in pediatric clinical practice [45]. This project however is focused exclusively on pediatric ADRs, therefore little is known about pediatric ADEs [46-48] and no study has previously explored pediatric MREs, in Italy.

Thus there remains a significant knowledge gap in our understanding the magnitude of MREs in pediatric population. The purpose of this report is to explore retrospectively the phenomenon of MREs in pediatric patients that result in ED visit.

\section{Methods}

We performed a retrospective cohort analysis reviewing all available electronic ED charts, collecting data from visits by children 0 to 14 years from 2007 to 2014 presenting to the ED of a single tertiary center, Azienda Ospedaliero-Universitaria Policlinico of Modena.

Independent investigators were full trained in predefined data-extraction criteria and the classification of Medication-Related Event visits (MRV) using a predefined approach [18, 39] Cases were randomly assigned. In case of ambiguous or conflicting events, a third investigators resolved the conflicts by discussing with the reviewers to achieve consensus [49].

Data were recorded anonymously on computerized abstraction forms (Microsoft Access 2011, Microsoft Corporation, Redmond, WA).

An ED visit was considered medication-related if the presentation was unequivocally related to the presenting chief concern and codified into 1 of 8 predefined categories, Table 1: ADR, drug interaction, improper drug selection, untreated indication, sub therapeutic dosage, supra-therapeutic dosage, non-adherence, and drug use without indication [50-53].

Both Naranjo Scale and World Health Organization (WHO) algorithm was used to determine causality [54, 55].

We considered an adverse drug related event as present if the WHO algorithm was deemed "certain" or "probable" or the Naranjo Scale was deemed "definite" or "probable" [18].

MRV severity was ranked as fatal, severe (life threatening or resulting in permanent disability), moderate (laboratory abnormality or symptom requiring treatment/ hospitalization or resulting in non-permanent disability) and mild (laboratory abnormality or symptom not requiring treatment) $[14,18]$. Potential MRV was included in our study. A potential MRV was defined as incidents with potential for injury related to a drug [7]. If treatment was started in order to prevent medical consequences we considered it as a potential MRV. We decided to evaluate potential MRV on the assumption that the causes of potential MRV are similar to the causes of true MRV [7].

We excluded drugs used for intentional self-harm and event caused by illicit drugs, nicotine, ethanol, nutritional supplements, complementary and alternative medication and assault by poisoning. Furthermore, we excluded ED visits that were made by the same patient.

Table 1 Categorization of Drug Related Problems [49]

\begin{tabular}{ll}
\hline ADR & $\begin{array}{l}\text { Any noxious, unintended, or undesired effect of a drug that occurs at doses used in humans for prophylaxis, diagnosis, } \\
\text { or treatment. These will include all reactions when drugs are used at appropriate doses and may include abnormal } \\
\text { laboratory values. }\end{array}$ \\
$\begin{array}{ll}\text { Untreated indication } \\
\text { Improper drug selection }\end{array}$ & $\begin{array}{l}\text { Any noxious, unintended, or undesired effect resulting from the failure to treat a known indication } \\
\text { indication }\end{array}$ \\
Subtherapeutic dosage & $\begin{array}{l}\text { Anynoxious,unintended,orundesiredeffectcausedbyfailuretoreceive sufficient drug dosage or duration for a given } \\
\text { indication or patient }\end{array}$ \\
Supratherapeutic dosage & $\begin{array}{l}\text { Any noxious, unintended, or undesired effect caused by excessive drug dose or duration for a given indication or } \\
\text { patient } \\
\text { Any noxious, unintended, or undesired effect caused by failure to receive a drug as prescribed by a health care } \\
\text { provider }\end{array}$ \\
Drug use without indication & $\begin{array}{l}\text { Any noxious, unintended, or undesired effect caused by the use of a drug for which there is no clear indication } \\
\text { Any noxious, unintended, or undesired effect caused by the coadministration of } 2 \text { or more drugs }\end{array}$
\end{tabular}


Narrative summaries, clinical testing, and physician's diagnoses from MRVs reports were coded according to Medical Dictionary for regulatory Activities (MedDRA) terminology and System Organ Class (SOC) list [56].

Medication involved in each event was classified according to anatomical therapeutic classification code (ATC).

The study was performed on the basis of the rules of Ethical Committee.

Descriptive analysis (mean and standard deviation for continuous data, absolute frequency and percentage for categorical data) was performed with STATISTICA ${ }^{\text {ma }}$ software (StatSoft Inc., Tulsa, OK, USA).
The primary outcome (Number of MRVs, Severity of True MRVs and Classification) of emergency department visits that were drug-related is reported as a percentage with $95 \%$ confidence interval (CI).

\section{Results}

Over the 8-year period a total of 147.643 patients presented to the ED, with a mean (SD) of 18.455 (805.7) visits per year.

A total of 497 MRVs $(0.34 \%, 95 \%$ CI $0.31 \%$ to $0.37 \%)$ were identified with the highest proportion of visits by children $0-2$ years old who accounted for $54 \%$ of visits.

Table 2 Demographic findings of patients $(n=497)$

\begin{tabular}{|c|c|c|c|}
\hline \multicolumn{2}{|l|}{ Characteristics } & \multicolumn{2}{|l|}{$\mathrm{n}(\%, 95 \% \mathrm{Cl})$} \\
\hline Age, mean (SD, Cl 95\%) & & $3.2(2.9,95 \% \mathrm{Cl} 0.31 \%$ to $0.37 \%))$ & \\
\hline \multicolumn{4}{|l|}{ age category } \\
\hline $0-2 y$ & & $269(54)$ & \\
\hline $2-6 y$ & & $168(33)$ & \\
\hline $6-14$ & & $60(13)$ & \\
\hline \multicolumn{4}{|l|}{ Gender } \\
\hline girl & & $225(45)$ & \\
\hline Boy & & $272(55)$ & \\
\hline \multicolumn{4}{|l|}{ Classification of MRVs $(n=497)$} \\
\hline Drug Use Without Indication & & $257(51)$ & \\
\hline ADR & & 152(30.3) & \\
\hline Supratherapeutic Dosage & & $66(13.2)$ & \\
\hline Improper Drug Selection & & $22(4.5)$ & \\
\hline True MRVs & & $232(46.5)$ & \\
\hline$A D R$ & & $152(65.5)$ & \\
\hline Medication related-ADRs & & $87(37.5)$ & \\
\hline Vaccination Related-ADRs & & $65(28)$ & \\
\hline Drug Use Without Indication & & 46(19.8) & \\
\hline Supratherapeutic Dosage & & 26(11.2) & \\
\hline Improper Drug Selection & & $8(3.5)$ & \\
\hline Potential MRVs & & $265(53.5)$ & \\
\hline Drug Use Without Indication & & $211(79.6)$ & \\
\hline Supratherapeutic Dosage & & $40(15.1)$ & \\
\hline Improper Drug Selection & & $14(5.3)$ & \\
\hline \multicolumn{4}{|l|}{ Degree of severity } \\
\hline & $\begin{array}{l}\text { True MRVs } \\
(n=232)\end{array}$ & $\begin{array}{l}\text { Medication related-ADRs } \\
\qquad(n=87)\end{array}$ & $\begin{array}{l}\text { VACCINES } \\
(n=65)\end{array}$ \\
\hline Mild & $50(21.6,95 \% \mathrm{Cl} 7.5 \%$ to $16.0 \%)$ & $16(18.4)$ & $12(18.5)$ \\
\hline Moderate & $156(67.295 \%$ Cl 60.7\% to $73.2 \%)$ & $66(75.8)$ & $52(80)$ \\
\hline Severe & $26(11.2,95 \% \mathrm{Cl} 16.4 \%$ to $27.4 \%)$ & $5(5.8)$ & $1(1.5)$ \\
\hline \multicolumn{4}{|l|}{ Outcome } \\
\hline Hospitalization & & $34(6.8)$ & \\
\hline Death & & - & \\
\hline
\end{tabular}


Drug use without indication-related visit accounted for 257 cases (51\%) followed by ADR-related visits 152 cases $(30,3 \%)$, supratherapeutic dosage-related visit 66 cases (13.2\%) and improper drug selection-related visit 22 cases (4.5\%) Table 2.

Potential MRVs was found in 265 cases (53.5\%) while a true MRV in 232 cases (46.5\%).

Among true MRVs the most common events were related to ADRs 152(65.5\%), followed by drug use without indication 46(19.8\%), supratherapeutic dosage 26(11.2\%), and improper drug selection $8(3.5 \%)$ while among potential MRVs the most common events were related to drug use without indication 211(79.6\%), followed by supratherapeutic dosage 40(15.1\%) and improper drug selection 14(5.3\%).

Medication-related ADRs accounted for 87 cases (37.5\%) while Vaccination-related ADRs accounted for 65 cases $(28 \%)$.

Severity classification was for True MRVs, mild in 50 cases $(21.6 \%, 95 \%$ CI $16.4 \%$ to $27.4 \%)$, moderate in 156 cases $(67.2 \%, 95 \%$ CI $60.7 \%$ to $73.2 \%)$, severe in 26 cases (11.2\%, $95 \% \mathrm{CI} 7.5 \%$ to $16.0 \%)$, for medication-related ADRs, severe in 5 cases (5.8\%), moderate in 66 cases (75.8\%), mild in 16 cases (18.4\%) and for Vaccine-related ADRs mild in 12 cases(18.5\%), moderate in 52 cases $(80 \%)$ and severe in 1 case $(1.5 \%)$.

Table 3 Medication Associated To MRVs

\begin{tabular}{|c|c|c|c|c|c|c|c|c|}
\hline \multicolumn{9}{|l|}{ ATC classes } \\
\hline \multirow[b]{2}{*}{ Antiinfectives for systemic use } & \multicolumn{2}{|c|}{$\begin{array}{l}\text { Total MRVs } \\
(n=497) \\
\mathrm{n}(\%)\end{array}$} & \multicolumn{2}{|c|}{$\begin{array}{l}\text { True MRVs } \\
(n=232) \\
\mathrm{n}(\%)\end{array}$} & \multicolumn{2}{|c|}{$\begin{array}{l}\text { Potential MRVs } \\
(n=265) \\
n(\%)\end{array}$} & \multicolumn{2}{|c|}{$\begin{array}{l}\text { Medication-related ADRs } \\
(n=87) \\
\mathrm{n}(\%)\end{array}$} \\
\hline & 144 & $(28.9)$ & 129 & $(55.6)$ & 15 & $(5.6)$ & 52 & $(59.7)$ \\
\hline Vaccines & 65 & $(45.1)$ & 65 & $(50.3)$ & - & - & - & - \\
\hline Beta-Lactam Antibacterials & 59 & $(40.9)$ & 47 & $(36.4)$ & 12 & $(80.0)$ & 43 & $(82.6)$ \\
\hline Macrolides, Lincosamides and Streptogramins & 15 & $(10.4)$ & 12 & $(9.3)$ & 3 & $(20)$ & 5 & $(9.6)$ \\
\hline Nervous System & 111 & $(22.3)$ & $40^{a}$ & $(17.2)$ & 71 & $(26.7)$ & 7 & $(8.0)$ \\
\hline Paracetamol & 34 & (30.6) & 13 & $(32.5)$ & 21 & $(29.5)$ & 1 & $(14.2)$ \\
\hline Psycholepticts & 29 & $(26.1)$ & 9 & $(22.5)$ & 20 & $(28.1)$ & - & - \\
\hline Antidepressants & 17 & $(15.3)$ & 7 & $(17.5)$ & 10 & $(14.0)$ & - & - \\
\hline Antiepileptics & 14 & $(12.6)$ & 5 & $(12.5)$ & 9 & $(12.6)$ & 3 & $(42.8)$ \\
\hline Opioids & 5 & $(4.5)$ & 1 & $(2.5)$ & 4 & $(5.6)$ & 1 & $(14.2)$ \\
\hline Respiratory System & 54 & $(10.8)$ & $14^{\mathrm{b}}$ & (6) & 40 & $(15$ & 6 & $(6.8)$ \\
\hline Adrenergics, Inhalants & 18 & (33.3) & 8 & $(57.1)$ & 10 & $(25)$ & 3 & $(50)$ \\
\hline Antihistamines for Systemic Use & 17 & $(31.4)$ & 3 & $(21.4)$ & 14 & $(35)$ & - & - \\
\hline Cough and Cold Preparations & 10 & $(18.5)$ & 2 & $(14.2)$ & 8 & $(20)$ & 2 & $(33.3$ \\
\hline Alimentary Tract and Metabolism & 52 & $(10.4)$ & $15^{c}$ & $(6.4)$ & 37 & $(13.9$ & 7 & $(8.0)$ \\
\hline $\begin{array}{l}\text { Drugs for Functional Gastrointestinal Disorders (domperidone, } \\
\text { metoclopramide, cimetropium bromide) }\end{array}$ & 15 & $(28.8)$ & 4 & $(26.6)$ & 11 & $(29.7)$ & 2 & $(28.5)$ \\
\hline Stomatological Preparations & 10 & $(19.2)$ & 1 & $(6.6)$ & 9 & $(24.3)$ & - & - \\
\hline Blood Glucose Lowering Drugs, Excl. Insulins & 7 & $(13.4)$ & 4 & $(26.6)$ & 3 & $(8.1)$ & - & - \\
\hline Vitamins & 6 & $(11.5)$ & 2 & $(13.3)$ & 4 & $(10.8)$ & 1 & $(14.2)$ \\
\hline Drugs for Acid Related Disorders & 4 & $(7.6)$ & - & - & $4^{11}$ & $(36.3)$ & - & - \\
\hline Antidiarrheals, Intestinal Antiinflammatory/Antiinfective Agents & 4 & $(7.6)$ & 1 & $(6.6)$ & 3 & $(8.1)$ & 1 & $(14.2)$ \\
\hline Drugs for Constipation & 3 & $(5.7)$ & 1 & $(6.6)$ & 2 & $(5.4)$ & 1 & $(14.2)$ \\
\hline Antiemetics and Antinauseants & 2 & $(3.8)$ & 2 & $(13.3)$ & - & - & 2 & $(28.5)$ \\
\hline Musculo-Skeletal System & 36 & $(7.2)$ & 14 & (6) & 22 & $(8.3)$ & 11 & $(12.6)$ \\
\hline NSAIDs (ketoprofen, ibuprofen) & 31 & $(86.1)$ & 14 & $(100)$ & 17 & $(77.2)$ & 11 & $(100)$ \\
\hline
\end{tabular}

${ }^{a} 18(45)$ cases were drug use without indication-related event, 10(25) cases were supratherapeutic dosage-related event, 5(12.5) cases were improper drug selection-related event;

${ }^{b} 5$ (35.7) cases were drug use without indication-related event, 2(14.2) cases were supratherapeutic dosage-related event, 1(7.1) cases were improper drug selection-related event;

${ }^{{ }^{5} 5(33.3)}$ cases were drug use without indication-related event, 3(20) cases were supratherapeutic dosage-related event; 
The medication classes most frequently implicated in the total MRVs were anti-infective drugs for systemic use (28.9\%, 95\% CI $25.0 \%$ to $33.1 \%$ ), central nervous system agents $(22.3 \%, 95 \%$ CI $18.7 \%$ to $26.2 \%)$ and respiratory system drugs $(10.8 \%, 95 \%$ CI $8.3 \%$ to $13.9 \%)$ Table 3.

Among MRVs related to anti-infective for systemic use $45.1 \%$ were the result of a vaccine, $40.9 \%$ were the result of a beta-lactam antibacterial and $10.4 \%$ of a macrolides.

Central nervous system agents-related events were most often linked to use of paracetamol (30.6\%), psycholepticts (26.1\%), antidepressants (15.3\%) and antiepileptic drugs (12.6\%). The majority of MREs involving respiratory system agents were associated with adrenergic inhalants (33.3\%) and antihistamines for systemic use (31.4\%).

Anti-infective drugs for systemic use (55.6\%) and Nervous system agents (17.2\%) are the major medication classes involved in true MRVs with respectively Vaccines (50.3\%), beta-lactam antibacterials (36.4\%), paracetamol (32.5\%) and psycoleptics (22.5\%). The major categories of medications involved in medication-related ADRs included anti-infective for systemic use $(59.7 \%)$ with an $82.6 \%$ of beta-lactam antibacterial involved while nervous system agents are the most common drug classes involved in MRVs not classifiable as an ADR. Table 4.

Dermatologic conditions were the most common true MRVs and Medication-Related ADRs manifestation, present respectively in $46.1 \%$ and in $88.5 \%$ of cases of true MRVs followed by general disorder and administration site conditions in $29.7 \%$ of cases and by gastrointestinal symptoms in $16.0 \%$ of cases of medication related ADRs. Table 5.

General disorders and administration site conditions were the most common Vaccination-Related ADR manifestation, present in $83.0 \%$ of cases followed by dermatologic conditions in $43.0 \%$ of cases. Table 5.
In $41.5 \%$ of cases the type of vaccines was not reported, severity was classified mostly moderate $(80 \%$ of cases) and type of reaction was manly systemic. Among the rest of available type of vaccines, Hexavalent (13.8\%), DTaP-MMR(12\%) and MMR(7.6\%) were predominantly associated with an MRV with a mild-moderate severity classification. Table 6.

\section{Discussion}

Definition and classification of ADEs was not standardized across different studies so we decided to study MREs following the more comprehensive and reproducible definition of Hepler and Strand [50]. This taxonomy provides a more accurate and inclusive evaluation of drug-related event and a meaningful characterization of MRVs in ED. In our analysis MRVs accounted for $0.34 \%$ of the ED visits appearing similar to the range of $0.5 \%$ to $3.3 \%$ found in previous studies [32, 52, 57-60].

To our knowledge the extent of MRVs presenting to ED, exclusively among the pediatric population, has not been previously studied in Italy.

Comparisons with the other Italian studies is challenging since there are limited researches that have investigated pediatric ADEs presenting to ED. Capuano et al. reported only $3(0.41 \%)$ patients aged $0-19$ years old presenting an ADE [46], Trifirò et al. reported 39(1.9\%) patients aged 019 years old [48] and Raschetti et al. reported 10(3.8\%) patients aged 0-20 years old [47]. Considering these studies, the sample size and the age range limit the possibilities for comparison.

More than two-thirds of true MRVs were identified as being moderate and mild as most commonly described in previous studies [32, 44, 52, 61, 62].

The rate of hospitalization (34 cases, 6.8\%) was a slightly greater than reported in the literature $(0.16-$

Table 4 Medication associated to MRVS not related to ADRs

\begin{tabular}{|c|c|c|c|c|c|c|}
\hline ATC classes & $\begin{array}{l}\text { True } \\
\text { Drug use } \\
\text { without } \\
\text { indication } \\
n=46 \\
n(\%)\end{array}$ & $\begin{array}{l}\text { Potential Drug use } \\
\text { without indication } \\
n=211 \\
n(\%)\end{array}$ & $\begin{array}{l}\text { True } \\
\text { Supratherapeutic } \\
\text { dosage } \\
n=26 \\
n(\%)\end{array}$ & $\begin{array}{l}\text { Potential } \\
\text { Supratherapeutic } \\
\text { dosage } \\
n=40 \\
n(\%)\end{array}$ & $\begin{array}{l}\text { True Improper } \\
\text { drug selection } \\
n=8 \\
n(\%)\end{array}$ & $\begin{array}{l}\text { Potential Improper } \\
\text { drug selection } \\
n=14 \\
n(\%)\end{array}$ \\
\hline Nervous System & $18(39.1)$ & $52(24.6)$ & $10(38.4)$ & $12(30)$ & $5(62.5)$ & $6(42.8)$ \\
\hline Cardiac & $5(10.8)$ & $27(12.8)$ & - & - & $1(12.5)$ & - \\
\hline Respiratory System & $5(10.8)$ & $27(12.8)$ & $2(7.7)$ & $9(22.5)$ & $1(12.5)$ & $4(28.5)$ \\
\hline $\begin{array}{l}\text { Alimentary Tract and } \\
\text { Metabolism }\end{array}$ & $5(10.8)$ & $24(11.3)$ & $3(11.5)$ & $9(22.5)$ & - & $4(28.5)$ \\
\hline Musculo-Skeletal System & $3(6.5)$ & $22(10.4)$ & - & - & - & - \\
\hline $\begin{array}{l}\text { Antiinfectives For } \\
\text { Systemic Use }\end{array}$ & $3(6.5)$ & $6(2.8)$ & $9(34.6)$ & $9(22.5)$ & - & - \\
\hline $\begin{array}{l}\text { Genito Urinary System } \\
\text { and Sex Hormones) }\end{array}$ & $1(2.1)$ & $22(10.4)$ & - & - & - & - \\
\hline
\end{tabular}


Table 5 Symptoms of pediatric MRVs

\begin{tabular}{|c|c|c|c|c|c|c|c|c|}
\hline \multicolumn{3}{|l|}{ Symptoms } & \multirow{2}{*}{\multicolumn{2}{|c|}{$\begin{array}{l}\text { Medication } \\
\text { related- } \\
\text { ADRs } \\
\mathrm{n}(\%)\end{array}$}} & \multirow[b]{2}{*}{$\begin{array}{l}\text { Vaccination Related- } \\
\text { ADRs } n(\%)\end{array}$} & \multirow[b]{2}{*}{$\begin{array}{l}\text { Drug use without } \\
\text { indication } \\
n(\%)\end{array}$} & \multirow[b]{2}{*}{$\begin{array}{l}\text { Supratherapeutic } \\
\text { dosage } \\
n(\%)\end{array}$} & \multirow[b]{2}{*}{$\begin{array}{l}\text { Improper drug } \\
\text { selection } \\
n(\%)\end{array}$} \\
\hline & $\begin{array}{l}\text { True } \\
n(\%)\end{array}$ & MRVs & & & & & & \\
\hline Skin and subcutaneous tissue disorders & 107 & $(46.1)$ & 77 & $(88.5)$ & $28(43.0)$ & $1(2.1)$ & $1(3.8)$ & - \\
\hline $\begin{array}{l}\text { General disorders and administration } \\
\text { site conditions }\end{array}$ & 69 & (29.7) & 9 & $(10.3)$ & $54(83.0)$ & $3(6.5)$ & $3(11.5)$ & - \\
\hline Gastrointestinal disorders & 56 & $(24.1)$ & 14 & $(16.0)$ & $8(12.3)$ & 18(39.1) & 14(53.8) & $2(25)$ \\
\hline Nervous system disorders & 30 & $(12.9)$ & 4 & (4.6) & $1(1.5)$ & $16(34.7)$ & $4(15.3)$ & $5(62.5)$ \\
\hline Eye disorders & 15 & $(6.4)$ & 9 & $(10.3)$ & $2(3.0)$ & $1(2.1)$ & $1(3.8)$ & $2(25)$ \\
\hline $\begin{array}{l}\text { Respiratory, thoracic and mediastinal } \\
\text { disorders }\end{array}$ & 15 & $(6.4)$ & 4 & $(4.6)$ & $6(9.2)$ & - & $4(15.3)$ & $1(12.5)$ \\
\hline Psychiatric disorders & 12 & (5.1) & 2 & (2.3) & $4(6.1)$ & $5(10.8)$ & 1(3.8) & - \\
\hline $\begin{array}{l}\text { Musculoskeletal and connective tissue } \\
\text { disorders }\end{array}$ & 7 & (3.0) & 1 & (1.1) & $3(4.6)$ & - & 2(7.6) & $1(12.5)$ \\
\hline
\end{tabular}

4.3\%) [63]. This increase should be interpreted in the light of the need to a prolonged period of observation.

As previously reported [52, 58, 64, 65] drug use without indication related visits and ADRs are the most common MRVs. These most commonly occurred after intake of anti-infective for systemic use agents, nervous system drugs and respiratory system agents causing dermatologic manifestation followed by general disorders, administration site conditions and gastrointestinal manifestation.

Among medication related-ADRs dermatological manifestation after beta-lactam antibacterial use is the most common disorder which is consistent with the findings of

Table 6 Reactions reported for each type of vaccines $(n=65)$

\begin{tabular}{|c|c|c|c|c|c|}
\hline \multirow{2}{*}{ TYPE n(\%) } & & & \multicolumn{3}{|c|}{ Type of reaction } \\
\hline & & & Systemic & Local & Systemic and Local \\
\hline Not Reported & 27 & $(41.54)$ & 21 & 4 & 2 \\
\hline Hexavalent & 9 & (13.85) & 7 & 2 & \\
\hline DTaP, MMR & 8 & $(12.31)$ & 1 & 5 & 2 \\
\hline MMR & 5 & (7.69) & 2 & 1 & 2 \\
\hline MMR, MEN C & 3 & $(4.62)$ & 3 & & \\
\hline DTaP, IPV & 3 & $(4.62)$ & & 2 & 1 \\
\hline HPV & 2 & $(3.08)$ & 2 & & \\
\hline PCV & 2 & (3.08) & 1 & 1 & \\
\hline PNEUMOVAX 23 & 2 & $(3.08)$ & & & 2 \\
\hline BCG & 1 & $(1.54)$ & & 1 & \\
\hline Нера B & 1 & $(1.54)$ & 1 & & \\
\hline MEN C & 1 & $(1.54)$ & & 1 & \\
\hline MMR, DTP, IPV & 1 & $(1.54)$ & & 1 & \\
\hline
\end{tabular}

DTaP difto-tetanus-pertussis vaccine, IPV inactivated antipolio vaccine, Hepa $B$ Hepatitis $B$ vaccine, Hib Haemophilus Influenzea type $B$ vaccine, MMR measles, mumps, rubella vaccine, $P C V$ pneumococcal eptavalente conjugate vaccine, MEN C meningococcal C conjugate vaccine, PNEUMOVAX 23 pneumococcal vaccine polyvalent, HEXAVALENT DTaP/Hib/IPV/HepB vaccine, BCG bacille Calmette-Guérin (BCG) vaccine the major national ADRs overview conducted in Italy from 2001 to 2012, collecting data from the Italian Pharmacovigilance Network database $[45,66]$.

Consistency of our data could be explained by a partial overlapping of the nature of pediatric population across the countries. This could probably be an echo of the scenery of disease prevalence and correlated medication use in children.

The results of research in adults could not be generalizable to children [67].

The European Regulation on Medicines for Pediatric use came into force on 26 January 2007 increased premarketing drug safety but efforts should take place at all levels to improve drug safety in a 'real-life' setting [66].

Kozer et al. [68] proposed some strategies that have the potential to reduce pediatric drug-related problems focusing on a 'system approach' view in which a medical error is a system error. PROTECT initiative [69], developed by The Centers for Disease Control and Prevention, delineated the key priorities for early action aimed to reduce medication errors.

There are several limitations in our study. First, the retrospective design of this study could underestimate the true incidence of MRVs. We consider the assessment of an experienced pharmacist and an independent physician both trained in recognition and resolution of MRVs to increase likelihood that all medication-related causes of an ED visit were identified and minimize potential misclassification.

Although we used an independent adjudication, process bias may have occurred in the categorization of the case summaries. Furthermore, retrospective analysis of data is limited by the impossibility to obtain additional information on the type of drug reaction.

Second, physicians may not have recognized a symptom as related to a medication; patient's report could 
have been incomplete or presenting with multiple problems. So it is possible that some cases were not classified as a MRV.

Third, conditions with significant impact like medication nonadherence and the related increased health care use in children and adolescent who have chronic medical condition were not evaluated [70].

Finally given the retrospective nature of the study and the involvement of one single hospital, our results are not necessarily generalizable to the pediatric ED setting.

\section{Conclusion}

MRVs are common medical complications among children in our setting and a challenge for the health care system. Our results are consistent with those from the current literature. Future prospective, large-sample sized, and multicenter research should focus in different settings on this topic to better understand the impact of MRV and the real effect of programmed preventive actions.

\section{Abbreviations}

ADEs: Adverse drug events; ADRs: Adverse drug reactions; ATC: Anatomical therapeutic classification code; ED: Emergency department; MEAP: Monitoring of the adverse effects in pediatric population; MedDRA: Medical Dictionary for regulatory activities terminology; MREs: Medication related events; MRV: Medication-Related Event visit; SOC: System Organ Class

\section{Acknowledgements}

Not applicable.

\section{Funding}

Not applicable.

\section{Availability of data and materials}

The datasets during and/or analysed during the current study available from the corresponding author on reasonable request.

\section{Authors' contributions}

CR: made substantial contributions to conception and design, or acquisition of data, or analysis and interpretation of data; been involved in drafting the manuscript or revising it critically for important intellectual content; given final approval of the version to be published. Each author should have participated sufficiently in the work to take public responsibility for appropriate portions of the content; and agreed to be accountable for all aspects of the work in ensuring that questions related to the accuracy or integrity of any part of the work are appropriately investigated and resolved. SP: made substantial contributions to conception and design, or acquisition of data, or analysis and interpretation of data; been involved in drafting the manuscript or revising it critically for important intellectual content; given final approval of the version to be published. Each author should have participated sufficiently in the work to take public responsibility for appropriate portions of the content; and agreed to be accountable for all aspects of the work in ensuring that questions related to the accuracy or integrity of any part of the work are appropriately investigated and resolved. CG: been involved in drafting the manuscript or revising it critically for important intellectual content; given final approval of the version to be published. Each author should have participated sufficiently in the work to take public responsibility for appropriate portions of the content; and VC: given final approval of the version to be published. Each author should have participated sufficiently in the work to take public responsibility for appropriate portions of the content; and agreed to be accountable for all aspects of the work in ensuring that questions related to the accuracy or integrity of any part of the work are appropriately investigated and resolved. NV: given final approval of the version to be published. Each author should have participated sufficiently in the work to take public responsibility for appropriate portions of the content; and agreed to be accountable for all aspects of the work in ensuring that questions related to the accuracy or integrity of any part of the work are appropriately investigated and resolved. PB: been involved in drafting the manuscript or revising it critically for important intellectual content; given final approval of the version to be published. Each author should have participated sufficiently in the work to take public responsibility for appropriate portions of the content; and agreed to be accountable for all aspects of the work in ensuring that questions related to the accuracy or integrity of any part of the work are appropriately investigated and resolved. LI: been involved in drafting the manuscript or revising it critically for important intellectual content; given final approval of the version to be published. Each author should have participated sufficiently in the work to take public responsibility for appropriate portions of the content; and agreed to be accountable for all aspects of the work in ensuring that questions related to the accuracy or integrity of any part of the work are appropriately investigated and resolved.

\section{Authors' information}

Not applicable.

\section{Competing interests}

The authors declare that they have no competing interests.

\section{Consent for publication}

Not applicable.

Ethics approval and consent to participate

The study was performed on the basis of the rules of Ethical Committee.

\section{Author details}

${ }^{1}$ Pediatric Unit, Post Graduate School of Pediatrics, University of Modena and Reggio Emilia, Viale del Pozzo, 71, 41124 Modena, Italy. ${ }^{2}$ Hospital Pharmacy Unit, Post Graduate School of Hospital Pharmacy, University of Modena and Reggio Emilia, Viale del Pozzo, 71, 41124 Modena, Italy. ${ }^{3}$ Department of Diagnostic, Clinical and Public Health Medicine, University of Modena and Reggio Emilia, Viale del Pozzo, 71, 41124 Modena, Italy. ${ }^{4}$ Hospital Pharmacy Unit, Department of Pharmacy, University of Modena and Reggio Emilia, Viale del Pozzo, 71, 41124 Modena, Italy. ${ }^{5}$ Pediatric Unit, Department of Medical and Surgical Sciences for Mothers, Children and Adults, University of Modena and Reggio Emilia, Viale del Pozzo, 71, 41124 Modena, Italy.

Received: 9 April 2017 Accepted: 6 June 2017

Published online: 13 June 2017

\section{References}

1. Nebeker JR, Barach P, Samore MH. Clarifying adverse drug events: a clinician's guide to terminology, documentation, and reporting. Ann Intern Med. 2004;140(10):795-801

2. Gurwitz D, McLeod HL. Primum non nocere: adverse drug events must be taken seriously. Pharmacogenomics. 2007;8(4):311-4.

3. Johnson JA, Bootman JL. Drug-related morbidity and mortality. A cost-ofillness model. Arch Intern Med. 1995;155(18):1949-56.

4. Bates DW, Spell N, Cullen DJ, Burdick E, Laird N, Petersen LA, et al. The costs of adverse drug events in hospitalized patients. Adverse Drug Events Prevention Study Group. JAMA. 1997;277(4):307-11.

5. Ernst FR, Grizzle AJ. Drug-related morbidity and mortality: updating the cost-of-illness model. J Am Pharm Assoc. 2001;41(2):192-9.

6. Baker GR, Norton PG, Flintoft V, Blais R, Brown A, Cox J, et al. The Canadian Adverse Events Study: the incidence of adverse events among hospital patients in Canada. CMAJ. 2004;170(11):1678-86.

7. Bates DW, Cullen DJ, Laird N, Petersen LA, Small SD, Servi D, et al. Incidence of adverse drug events and potential adverse drug events. Implications for prevention. ADE Prevention Study Group. JAMA. 1995;274(1):29-34.

8. Nelson KM, Talbert RL. Drug-related hospital admissions. Pharmacotherapy. 1996;16(4):701-7.

9. Classen DC, Pestotnik SL, Evans RS, Lloyd JF, Burke JP. Adverse drug events in hospitalized patients. Excess length of stay, extra costs, and attributable mortality. JAMA. 1997;277(4):301-6. 
10. Lazarou J, Pomeranz BH, Corey PN. Incidence of adverse drug reactions in hospitalized patients: a meta-analysis of prospective studies. JAMA. 1998; 279(15):1200-5.

11. Lagnaoui R, Moore N, Fach J, Longy-Boursier M, Begaud B. Adverse drug reactions in a department of systemic diseases-oriented internal medicine: prevalence, incidence, direct costs and avoidability. Eur J Clin Pharmacol. 2000;56(2):181-6.

12. McDonnell PJ, Jacobs MR. Hospital admissions resulting from preventable adverse drug reactions. Ann Pharmacother. 2002;36(9):1331-6.

13. Peyriere H, Cassan S, Floutard E, Riviere S, Blayac JP, Hillaire-Buys D, et al. Adverse drug events associated with hospital admission. Ann Pharmacother. 2003;37(1):5-11.

14. Pirmohamed M, James S, Meakin S, Green C, Scott AK, Walley TJ, et al. Adverse drug reactions as cause of admission to hospital: prospective analysis of 18820 patients. BMJ. 2004;329(7456):15-9.

15. Samoy LJ, Zed PJ, Wilbur K, Balen RM, Abu-Laban RB, Roberts M. Drug-related hospitalizations in a tertiary care internal medicine service of a Canadian hospital: a prospective study. Pharmacotherapy. 2006;26(11):1578-86

16. Kaiser RM, Schmader KE, Pieper CF, Lindblad Cl, Ruby CM, Hanlon JT. Therapeutic failure-related hospitalisations in the frail elderly. Drugs Aging. 2006;23(7):579-86

17. Sikdar KC, Alaghehbandan R, MacDonald D, Barrett B, Collins KD, Donnan J, et al. Adverse drug events in adult patients leading to emergency department visits. Ann Pharmacother. 2010;44(4):641-9.

18. Zed PJ, Abu-Laban RB, Balen RM, Loewen PS, Hohl CM, Brubacher JR, et al. Incidence, severity and preventability of medication-related visits to the emergency department: a prospective study. CMAJ. 2008;178(12):1563-9.

19. Hohl CM, Robitaille C, Lord V, Dankoff J, Colacone A, Pham L, et al. Emergency physician recognition of adverse drug-related events in elder patients presenting to an emergency department. Acad Emerg Med. 2005;12(3):197-205.

20. Bannwarth B, Queneau P, Carpentier F, Guliana JM, Bouget J, Trombert B, et al. Hospital visits caused by adverse drug reactions: incidence and preventability assessed in French primary care/emergency departments. Drug Saf. 2003;26(2):133-4.

21. Malhotra S, Karan RS, Pandhi P, Jain S. Drug related medical emergencies in the elderly: role of adverse drug reactions and non-compliance. Postgrad Med J. 2001;77(913):703-7.

22. Olshaker JS, Barish RA, Naradzay JF, Jerrard DA, Safir E, Campbell L. Prescription noncompliance: contribution to emergency department visits and cost. J Emerg Med. 1999;17(5):909-12.

23. Tafreshi MJ, Melby MJ, Kaback KR, Nord TC. Medication-related visits to the emergency department: a prospective study. Ann Pharmacother. 1999;33(12): $1252-7$.

24. Hafner JW Jr, Belknap SM, Squillante MD, Bucheit KA. Adverse drug events in emergency department patients. Ann Emerg Med. 2002;39(3):258-67.

25. Hohl CM, Dankoff J, Colacone A, Afilalo M. Polypharmacy, adverse drug-related events, and potential adverse drug interactions in elderly patients presenting to an emergency department. Ann Emerg Med. 2001;38(6):666-71.

26. Shehab N, Patel PR, Srinivasan A, Budnitz DS. Emergency department visits for antibiotic-associated adverse events. Clin Infect Dis. 2008;47(6):735-43.

27. Budnitz DS, Pollock DA, Weidenbach KN, Mendelsohn AB, Schroeder TJ, Annest JL. National surveillance of emergency department visits for outpatient adverse drug events. JAMA. 2006;296(15):1858-66.

28. Yee $J$, Hasson NK, Schreiber DH. Drug-related emergency department visits in an elderly veteran population. Ann Pharmacother. 2005;39(12):1990-5.

29. Aparasu RR. Drug-related-injury visits to hospital emergency departments. American journal of health-system pharmacy. AJHP. 1998;55(11):1158-61.

30. Aparasu RR. Visits to office-based physicians in the United States for medication-related morbidity. J Am Pharm Assoc. 1999;39(3):332-7.

31. Aparasu RR, Helgeland DL. Utilization of ambulatory care services caused by adverse effects of medications in the United States. Manag Care Interface. 2000;13(4):70-5

32. Smith KM, McAdams JW, Frenia ML, Todd MW. Drug-related problems in emergency department patients. AJHP. 1997;54(3):295-8.

33. Schneitman-McIntire O, Farnen TA, Gordon N, Chan J, Toy WA. Medication misadventures resulting in emergency department visits at and $\mathrm{HMO}$ medical center. AJHP. 1996;53(12):1416-22.

34. Dennehy CE, Kishi DT, Louie C. Drug-related illness in emergency department patients. Am J Health Syst. 1996;53(12):1422-6.

35. Stoukides CA, D'Agostino PR, Kaufman MB. Adverse drug reaction surveillance in an emergency room. Am J Hosp Pharm. 1993;50(4):712-4.
36. Prince BS, Goetz CM, Rihn TL, Olsky M. Drug-related emergency department visits and hospital admissions. Am J Hosp Pharm. 1992:49(7):1696-700.

37. Patel P, Zed PJ. Drug-related visits to the emergency department: how big is the problem? Pharmacotherapy. 2002;22(7):915-23.

38. Leendertse AJ, Egberts AC, Stoker LJ, van den Bemt PM, Group HS. Frequency of and risk factors for preventable medication-related hospital admissions in the Netherlands. Arch Intern Med. 2008;168(17):1890-6.

39. Forster AJ, Clark HD, Menard A, Dupuis N, Chernish R, Chandok N, et al. Adverse events among medical patients after discharge from hospital. Can Med Assoc J. 2004;170(3):345-9.

40. Gandhi TK, Weingart SN, Borus J, Seger AC, Peterson J, Burdick E, et al. Adverse drug events in ambulatory care. N Engl J Med. 2003;348(16):1556-64.

41. Gurwitz JH, Field TS, Harrold LR, Rothschild J, Debellis K, Seger AC, et al. Incidence and preventability of adverse drug events among older persons in the ambulatory setting. JAMA. 2003:289(9):1107-16.

42. Thomsen LA, Winterstein AG, Sondergaard B, Haugbolle LS, Melander A. Systematic review of the incidence and characteristics of preventable adverse drug events in ambulatory care. Ann Pharmacother. 2007;41(9):1411-26.

43. Tache SV, Sonnichsen A, Ashcroft DM. Prevalence of adverse drug events in ambulatory care: a systematic review. Ann Pharmacother. 2011;45(7-8):977-89.

44. Sikdar KC, Alaghehbandan R, Macdonald D, Barrett B, Collins KD, Gadag V. Adverse drug events among children presenting to a hospital emergency department in Newfoundland and Labrador, Canada. Pharmacoepidemiol Drug Saf. 2010;19(2):132-40.

45. Carnovale C, Brusadelli T, Zuccotti G, Beretta S, Sullo MG, Capuano A, et al. The importance of monitoring adverse drug reactions in pediatric patients: the results of a national surveillance program in Italy. Expert Opin Drug Saf. 2014;13(Suppl 1):S1-8.

46. Capuano A, Irpino A, Gallo M, Ferrante L, Illiano ML, Rinaldi B, et al. Regional surveillance of emergency-department visits for outpatient adverse drug events. Eur J Clin Pharmacol. 2009;65(7):721-8.

47. Raschetti R, Morgutti M, Menniti-Ippolito F, Belisari A, Rossignoli A, Longhini $P$, et al. Suspected adverse drug events requiring emergency department visits or hospital admissions. Eur J Clin Pharmacol. 1999:54(12):959-63.

48. Trifiro G, Calogero G, Ippolito FM, Cosentino M, Giuliani R, Conforti A, et al. Adverse drug events in emergency department population: a prospective Italian study. Pharmacoepidemiol Drug Saf. 2005;14(5):333-40.

49. Zed PJ, Black KJ, Fitzpatrick EA, Ackroyd-Stolarz S, Murphy NG, Curran JA, et al. Medication-related emergency department visits in pediatrics: a prospective observational study. Pediatrics. 2015;135(3):435-43.

50. Hepler CD, Strand LM. Opportunities and responsibilities in pharmaceutical care. Am J Hosp Pharm. 1990;47(3):533-43.

51. Feinstein JA, Feudtner C, Kempe A. Adverse drug event-related emergency department visits associated with complex chronic conditions. Pediatrics. 2014;133(6):e1575-85

52. Easton-Carter KL, Chapman CB, Brien JE. Emergency department attendances associated with drug-related problems in paediatrics. J Paediatr Child Health. 2003;39(2):124-9.

53. Strand LM, Morley PC, Cipolle RJ, Ramsey R, Lamsam GD. Drug-related problems: their structure and function. Ann Pharmacother. 1990;24(11):1093-7.

54. Naranjo CA, Busto U, Sellers EM, Sandor P, Ruiz I, Roberts EA, et al. A method for estimating the probability of adverse drug reactions. Clin Pharmacol Ther. 1981;30(2):239-45.

55. International drug monitoring. The role of the hospital. World Health Organ Tech Rep Ser. 1969:425:5-24. http://apps.who.int/iris/bitstream/10665/ 40747/1/WHO_TRS_425.pdf. Accessed 13 Nov 2016

56. Bousquet C, Sadou E, Souvignet J, Jaulent MC, Declerck G. Formalizing MedDRA to support semantic reasoning on adverse drug reaction terms. Biomed Inform. 2014:49:282-91.

57. Cohen AL, Budnitz DS, Weidenbach KN, Jernigan DB, Schroeder TJ, Shehab N, et al. National surveillance of emergency department visits for outpatient adverse drug events in children and adolescents. J Pediatr. 2008;152(3):416-21.

58. Bourgeois FT, Mandl KD, Valim C, Shannon MW. Pediatric adverse drug events in the outpatient setting: an 11-year national analysis. Pediatrics. 2009;124(4):e744-50.

59. Schillie SF, Shehab N, Thomas KE, Budnitz DS. Medication overdoses leading to emergency department visits among children. Am J Prev Med. 2009; 37(3):181-7.

60. Phan H, Leder M, Fishley M, Moeller M, Nahata M. Off-label and unlicensed medication use and associated adverse drug events in a pediatric emergency department. Pediatr Emerg Care. 2010;26(6):424-30. 
61. Martinez-Mir I, Garcia-Lopez M, Palop V, Ferrer JM, Estan L, Rubio E, et al. A prospective study of adverse drug reactions as a cause of admission to a paediatric hospital. Br J Clin Pharmacol. 1996;42(3):319-24.

62. Lamabadusuriya SP, Sathiadas G. Adverse drug reactions in children requiring hospital admission. Ceylon Med J. 2003;48(3):86-7.

63. Zed PJ, Haughn C, Black KJ, Fitzpatrick EA, Ackroyd-Stolarz S, Murphy NG, et al. Medication-related emergency department visits and hospital admissions in pediatric patients: a qualitative systematic review. J Pediatr. 2013;163(2):477-83.

64. Easton KL, Chapman CB, Brien JA. Frequency and characteristics of hospita admissions associated with drug-related problems in paediatrics. Br J Clin Pharmacol. 2004;57(5):611-5.

65. Easton KL, Parsons BJ, Starr M, Brien JE. The incidence of drug-related problems as a cause of hospital admissions in children. Med J Aust. 1998; 169(7):356-9.

66. Ferrajolo C, Capuano A, Trifiro G, Moretti U, Rossi F, Santuccio C. Pediatric drug safety surveillance in Italian pharmacovigilance network: an overview of adverse drug reactions in the years 2001 - 2012. Expert Opin Drug Saf. 2014;13(Suppl 1):S9-20.

67. Zed PJ. Medication-Related Emergency Department Visits and Hospital Admissions in Pediatric Patients: A Qualitative Systematic Review. J Pediatr. 2013:163:477-83.

68. Kozer E, Berkovitch M, Koren G. Medication errors in children. Pediatr Clin N Am. 2006:53(6):1155-68.

69. Centers for Disease Control and Prevention. The PROTECT initiative: advancing children's medication safety. 2012.http://www.cdc.gov/ medicationsafety/protect/protect_initiative.html. Accessed 2 July.

70. McGrady ME, Hommel KA. Medication adherence and health care utilization in pediatric chronic illness: a systematic review. Pediatrics. 2013;132(4):730-40.

\section{Submit your next manuscript to BioMed Central and we will help you at every step:}

- We accept pre-submission inquiries

- Our selector tool helps you to find the most relevant journal

- We provide round the clock customer support

- Convenient online submission

- Thorough peer review

- Inclusion in PubMed and all major indexing services

- Maximum visibility for your research

Submit your manuscript at www.biomedcentral.com/submit

C) Biomed Central 